Article

\title{
Co-Exchange of Mn: A Simple Method to Improve Both the Hydrothermal Stability and Activity of $\mathrm{Cu}-\mathrm{SSZ}-13 \mathrm{NH}_{3}-\mathrm{SCR}$ Catalysts
}

\author{
Chaoming Song ${ }^{1}$, Lihong Zhang ${ }^{1, * \mathbb{C}}$, Zhenguo $\mathrm{Li}^{2,3}$, Yiren $\mathrm{Lu}^{4, *}$ and Kaixiang $\mathrm{Li}^{2,3}$ \\ 1 Department of Catalysis Science and Technology and Tianjin Key Laboratory of Applied Catalysis Science \& \\ Technology, School of Chemical Engineering and Technology, Tianjin University, Tianjin 300350, China; \\ scm13303725721@sina.com \\ 2 Automotive Engineering Research Institute, China Automotive Technology and Research Center Co., Ltd., \\ Tianjin 300300, China; lizhenguo@catarc.ac.cn (Z.L.); likaixiang@catarc.ac.cn (K.L.) \\ 3 National Engineering Laboratory for Mobile Source Emission Control Technology, Tianjin 300300, China \\ 4 School of Environmental Science and Engineering, Tianjin University, Tianjin 300072, China \\ * Correspondence: zlh_224@163.com (L.Z.); luyiren@tju.edu.cn (Y.L.)
}

Received: 24 April 2019; Accepted: 14 May 2019; Published: 17 May 2019

check for updates

\begin{abstract}
A series of $\mathrm{Cu}-\mathrm{Mn}-\mathrm{SSZ}-13$ catalysts were obtained by co-exchange of $\mathrm{Mn}$ and $\mathrm{Cu}$ into SSZ-13 together (ion exchange under a mixed solution of $\mathrm{Cu}\left(\mathrm{NO}_{3}\right)_{2}$ and $\left.\mathrm{Mn}\left(\mathrm{NO}_{3}\right)_{2}\right)$ and compared with $\mathrm{Cu}-\mathrm{SSZ}-13$ catalysts on the selective catalytic reduction (SCR) of nitric oxide (NO) by ammonia. The effects of total ion exchange degree and the effect of $\mathrm{Mn}$ species on the structure and performance of catalysts before and after hydrothermal aging were studied. All fresh and aged catalysts were characterized with several methods including temperature-programmed desorption with $\mathrm{NH}_{3}$ $\left(\mathrm{NH}_{3}\right.$-TPD), X-ray diffraction (XRD), ${ }^{27} \mathrm{Al}$ and ${ }^{29} \mathrm{Si}$ solid-state nuclear magnetic resonance (NMR), scanning electron microscopy-energy dispersive spectroscopy (SEM-EDS) and low-temperature $\mathrm{N}_{2}$ adsorption-desorption techniques. The results showed that the increase of the total ion exchange degree can reduce the content of residual Brønsted acid sites of catalysts, thus relieved the dealumination and the decrease of crystallinity of the catalyst during hydrothermal aging. The moderate addition of a Mn component in $\mathrm{Cu}-\mathrm{Mn}-\mathrm{SSZ}-13$ catalysts significantly increased the activity of NO conversion at low temperature range. The selected $\mathrm{Cu}(0.2) \mathrm{Mn}(0.1)-\mathrm{SSZ}-13$ catalyst achieved a high $\mathrm{NO}$ conversion of $>90 \%$ in the wide and low temperature range of $175-525^{\circ} \mathrm{C}$ and also exhibited good $\mathrm{N}_{2}$ selectivity and excellent hydrothermal stability, which was related to the inhibition of the Mn component on the aggregation of $\mathrm{Cu}$ species and the pore destruction of the catalyst during hydrothermal aging.
\end{abstract}

Keywords: Selective catalytic reduction; nitric oxide; ammonia; SSZ-13; hydrothermal aging

\section{Introduction}

Nitrogen oxides $\left(\mathrm{NO}_{\mathrm{x}}\right)$ emitted from mobile or stationary sources are among the major sources of air pollution, leading to a number of environmental problems such as photochemical smog and acid rain, which have great negative impacts on human health [1-5]. Owing to their negative environmental and health impacts, the removal of $\mathrm{NO}_{\mathrm{x}}$ is becoming increasingly urgent. In addition to modifications made to combustion systems to reduce $\mathrm{NO}_{\mathrm{x}}$ emissions, exhaust after-treatment technologies are required to meet stringent pollution control standards. In recent years, the selective catalytic reduction (SCR) of $\mathrm{NO}_{x}$ with $\mathrm{NH}_{3}$ was proven to be an efficient method, regarded as one of the most promising candidates for $\mathrm{NO}_{\mathrm{x}}$ reduction in flue gas [6-10]. 
A catalyst is one of the key components of an SCR system. Recently, the Cu-SSZ-13 catalyst with a Chabazite (CHA) structure—of which largest pore has an opening of $3.8 \AA$ (eight-membered ring)—has gained attention owing to its high activity, stability, and selectivity [11-15]. The catalyst can maintain a high catalytic activity and excellent $\mathrm{N}_{2}$ selectivity over a wide temperature range $\left(250-550{ }^{\circ} \mathrm{C}\right)$, which is much better than the V-based and $\mathrm{Cu}-\mathrm{ZSM}-5$ catalysts $[10,16]$. However, this catalyst fails to meet the actual use conditions of diesel vehicles in the cold startup stage, which require better low-temperature activity $[3,17,18]$. Moreover, the vapor always emits from the lean combustion engine and the exhaust temperature can reach above $800^{\circ} \mathrm{C}$ after diesel particulate filter (DPF) regeneration, thus the catalyst would undergo a high temperature hydrothermal aging process [19-21]. Therefore, it is necessary to improve the catalyst's low-temperature activity and its resistance to hydrothermal aging.

During the past years, many efforts have been made to solve these two problems. Steven et al. systematically studied the hydrothermal resistance of a commercial $\mathrm{Cu}-\mathrm{SSZ}-13$ catalyst and proposed a method for rapid hydrothermal aging. They found that the catalyst aged in the selected reactor aging conditions $\left(800^{\circ} \mathrm{C}\right)$ was comparable to the catalytic performance and characterization criteria of the 135,000-mile automotive aged catalyst [20]. In order to improve the hydrothermal stability of the catalyst, Gao. et al. introduced alkali metal ions and alkaline earth metal ions into the Cu-SSZ-13 catalyst, which had a notable effect due to the removal of the Brønsted (B) acid sites of the catalyst [22]. Meanwhile the mechanism of the hydrothermal aging of the catalyst has also attracted much attention. For example, Song et al. presented an atomic-level understanding of changes to the zeolite and the $\mathrm{Cu}$ active sites during hydrothermal aging and pointed out that the diffusion of $\mathrm{Cu}_{\mathrm{x}} \mathrm{O}_{\mathrm{y}}$ clusters which is larger than the primary pore openings of SSZ-13 can be regarded as a primary cause for the structure damage of this catalyst [23]. As for the low-temperature activity, Liu et al. created a novel SCR catalyst with $\mathrm{MnO}_{x}-\mathrm{CeO}_{2}$ supported on $\mathrm{Cu}-\mathrm{SSZ}-13$ which reached an $\mathrm{NO}$ conversion efficiency of over $90 \%$ at $150{ }^{\circ} \mathrm{C}$. Furthermore, they found that adding $\mathrm{MnO}_{\mathrm{x}}-\mathrm{CeO}_{2}$ facilitated the conversion of bridging nitrate to monodentate nitrate, which might be the reason for the improved activity [24]. Meanwhile, considerable Mn-based and Ce-based oxide catalysts were investigated due to their excellent low-temperature SCR activities [25-28].

However, it is difficult to improve the catalyst's low-temperature activity and its resistance to hydrothermal aging simultaneously. Especially for the Cu-SSZ-13 catalyst, a high Cu ion exchange level is favorable for high activity at low temperature, while it is quite harmful to hydrothermal stability, so it is difficult to improve these two aspects by simply adjusting the $\mathrm{Cu}$ content $[20,22,23]$. By introducing Mn ions using the co-exchange mothed, we solve this problem ingeniously. Furthermore, most methods for increasing the low-temperature activity of the catalyst are accompanied by a decrease in the high-temperature activity $[24,27,29]$. Our method not only can improve the low-temperature activity but also can maintain the high-temperature activity stably. The novel $\mathrm{Cu}(0.2) \mathrm{Mn}(0.1)$ catalyst can obtain over $90 \% \mathrm{NO}$ conversion at $525^{\circ} \mathrm{C}$, which is equivalent to the high-temperature activity of the ordinary $\mathrm{Cu}-\mathrm{SSZ}-13$ catalysts. Meanwhile, the novel $\mathrm{Cu}(0.2) \mathrm{Mn}(0.1)$ catalyst maintains a better performance than the ordinary $\mathrm{Cu}-\mathrm{SSZ}-13$ catalyst after hydrothermal aging. The wide temperature window and high hydrothermal stability meet the complex operating conditions and durability requirements of diesel engines, indicating broad application prospects and good business value.

\section{Results and Discussion}

\subsection{Activity Test}

The XRD curve and SEM images of synthetic SSZ-13 zeolite are shown in Figures S1 and S2. The result indicates the zeolite presents obvious CHA structural features [30,31].

Figure 1 shows the $\mathrm{NH}_{3}$-SCR activity of these $\mathrm{Cu}-\mathrm{Mn}$ catalysts. As the $\mathrm{Mn} / \mathrm{Cu}$ ratio (in the mother liquid) rose from $0 / 10$ to $4 / 10$, the activity of the catalyst at low temperature increased and the temperature at NO conversion of $90 \%$ decreased from 225 to $175{ }^{\circ} \mathrm{C}$. This indicates that the $\mathrm{Cu}-\mathrm{Mn}$ catalysts obtained by co-exchange method can achieve good activity at both low and high 
temperature. However, the $\mathrm{Mn}_{\mathrm{x}} \mathrm{O}_{\mathrm{y}}$-based, $\mathrm{Mn}_{\mathrm{x}} \mathrm{O}_{\mathrm{y}}$-modified or $\mathrm{Mn}_{\mathrm{x}} \mathrm{O}_{\mathrm{y}}$-SSZ-13 catalysts can only improve low-temperature $\mathrm{NH}_{3}$-SCR properties [24,25,32-34]. This is due to the fact that the $\mathrm{Mn}$ element here was introduced into the SSZ-13 zeolite in the form of stable and well-dispersed metal ions instead of big $\mathrm{Mn}_{\mathrm{x}} \mathrm{O}_{\mathrm{y}}$ particles. The XRD results (Figure S3) shows that the $\mathrm{Cu}-\mathrm{Mn}$ catalysts had the feature of the $\mathrm{CHA}$ structure. It was difficult to form the $\mathrm{Mn}_{\mathrm{x}} \mathrm{O}_{\mathrm{y}}$ particles on the surface of $\mathrm{Cu}-\mathrm{Mn}$ catalysts, since the concentration of the ionic solution used for exchange was quite dilute and the catalysts were rinsed by deionized water after exchange. However, the activity decreased when the $\mathrm{Mn} / \mathrm{Cu}$ ratio reached 6/10 and the feature presented a seagull-shape showing an interesting phenomenon that from $\sim 150$ to $\sim 250{ }^{\circ} \mathrm{C}$ the NO conversion decreased. This occurs when the gas hourly space velocity (GHSV) is relatively high $[35,36]$, therefore, when the $\mathrm{Mn} / \mathrm{Cu}$ ratio increased to 6/10,Mn ions competed with the $\mathrm{Cu}$ ions violently then the content of $\mathrm{Cu}$ ions decreased as shown in Table 1 , which leads to an increase of relative GHSV.

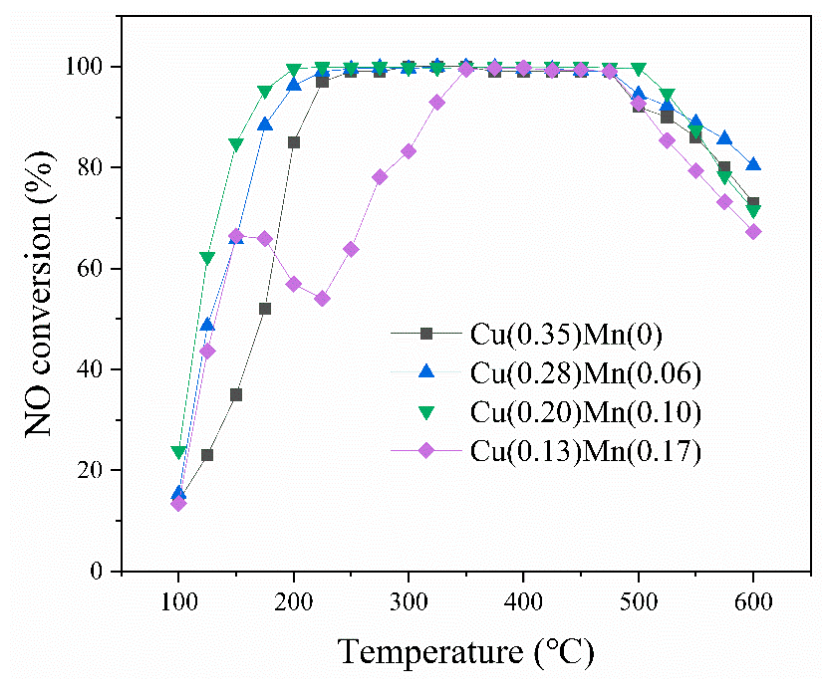

Figure 1. NO conversion of catalysts with different $\mathrm{Mn} / \mathrm{Cu}$ ratios under a gas hourly space velocity (GHSV) of 30,000 $\mathrm{h}^{-1}$.

Table 1. Ion exchange degree of catalysts with different $\mathrm{Mn} / \mathrm{Cu}$ molar ratios.

\begin{tabular}{ccccc}
\hline Mn/Cu Ratio & $0 / 10$ & $2 / 10$ & $4 / 10$ & $6 / 10$ \\
Ion Exchange Degree of $\mathbf{C u}^{\text {a }}$ & 0.35 & 0.28 & 0.20 & 0.13 \\
Ion Exchange Degree of $\mathbf{M n}^{\text {a }}$ & 0 & 0.06 & 0.10 & 0.17 \\
\hline
\end{tabular}

a Ion exchange degree calculated from the equation of $\mathrm{mol} \mathrm{Cu}($ or $\mathrm{Mn}) \times 2 / \mathrm{mol} \mathrm{Al} \times 100 \%$ based on the inductively coupled plasma atomic emission spectroscopy (ICP-AES) results.

In order to understand the effect of Mn species, we used $\mathrm{Cu}(0.2)$ and $\mathrm{Cu}(0.3)$ samples (with the same $\mathrm{Cu}$ content and the same total ion exchange degree as the $\mathrm{Cu}(0.2) \mathrm{Mn}(0.1)$ catalyst) for comparison. It should be noted that it is difficult to obtain the exact same ion exchange degree or the same $\mathrm{Cu}$ content by the ion exchange method, so we used approximate processing.

The temperature programmed reduction with hydrogen $\left(\mathrm{H}_{2}-\mathrm{TPR}\right)$ curves given in Figure $\mathrm{S} 4$ show that the addition of Mn can make the reduction peak at ca. $220^{\circ} \mathrm{C}$ enlargen and broaden due to the occurrence of shoulder peak at the side of high temperature. It indicates the addition of Mn species can interact with $\mathrm{Cu}$ ions and weak the interaction between $\mathrm{Cu}$ ions and the CHA framework. It is beneficial to the low-temperature SCR activity [22]. The formation of $\mathrm{NO}_{2}$ from $\mathrm{NO}$ is a key step in standard SCR reactions [37]. The increase in the oxidizing ability of the catalyst made the reaction easier to occur and thereby increased the low temperature activity of the $\mathrm{Cu}-\mathrm{Mn}$ catalyst. On the other hand, the introduction of $\mathrm{Mn}$ species by the co-exchange method caused an increase in the total ion exchange degree, leading to a decrease of the residual B acid sites, which are activity-silent [37-40] 
and vulnerable during hydrothermal aging. Another important conclusion of this result is that the decrease of the residual $\mathrm{B}$ acid sites also can improve the stability of $\mathrm{Cu}-\mathrm{Mn}$ catalyst $[22,41]$.

From Figure 2a, we can see the $\mathrm{Cu}(0.2) \mathrm{Mn}(0.1)$ catalyst presents the widest active temperature window. For the $\mathrm{Cu}(0.2)$ and $\mathrm{Cu}(0.3)$ samples, they were similar in activity at high temperatures and the $\mathrm{Cu}(0.3)$ catalyst had a higher activity in the low temperature range since it contained more active components. However, their activity in the low-temperature range was much lower than that of $\mathrm{Cu}(0.2) \mathrm{Mn}(0.1)$, indicating that the increase of activity was not caused by the increase in ion exchange degree but was mainly caused by the promotion of Mn species. Compared with Figure 1 and the literature, we found that the temperature at which the seagull-like curve inflection appeared was different, meaning that the interaction between $\mathrm{Cu}$ and $\mathrm{Mn}$ changed the transition temperature $[35,36]$. This indicates that $\mathrm{Cu}^{2+}$ and $\mathrm{Mn}$ species interact with each other. The $\mathrm{N}_{2}$ selectivity of all catalysts exceeded $95 \%$ throughout all of the temperature range, showing that this method not only increased activity, but also maintained high $\mathrm{N}_{2}$ selectivity.
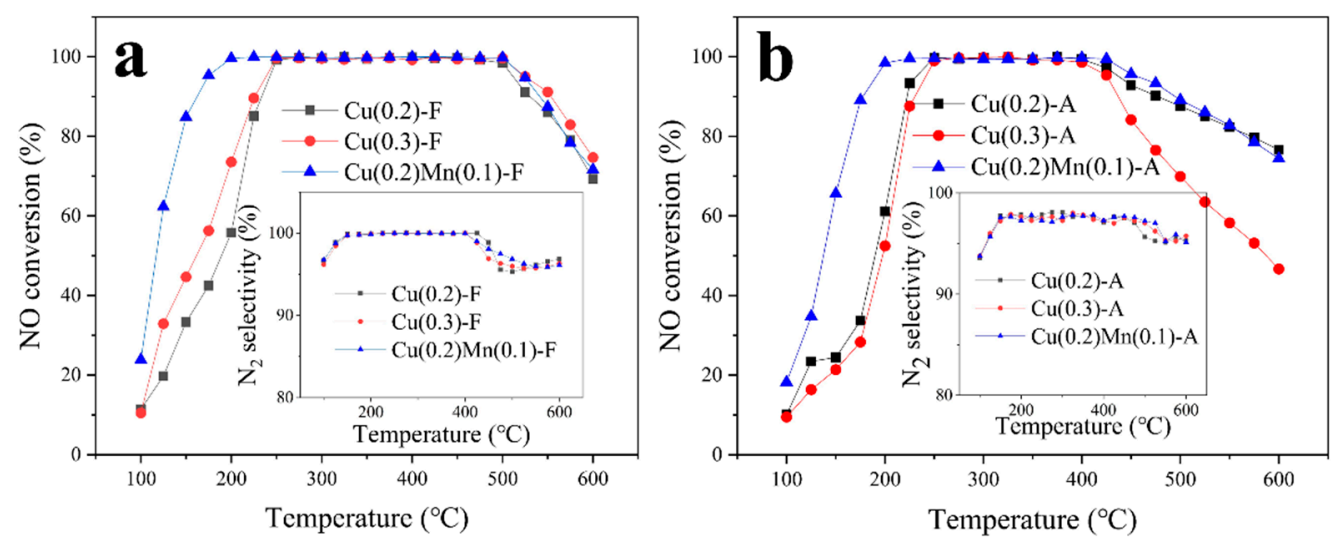

Figure 2. NO conversion with catalysts before (a) and after (b) hydrothermal aging under a GHSV of $30,000 \mathrm{~h}^{-1}$.

Hydrothermal aging is one of the common reasons for the deactivation of $\mathrm{NH}_{3}$-SCR catalysts for diesel vehicles and it is important to evaluate the catalytic activity of catalysts after hydrothermal aging. Figure $2 b$ is the activity curve of the catalysts after hydrothermal aging. As it shows, all the catalysts had varying degrees of deterioration compared with the fresh sample and the $\mathrm{Cu}(0.2) \mathrm{Mn}(0.1)$ still possessed the best catalytic activity and maintained more than $90 \%$ NO conversion in the range of $180-475^{\circ} \mathrm{C}$. This indicates that it exhibits not only remarkable low temperature activity but also excellent hydrothermal stability, which is quite beneficial for the practical application of commercial SCR catalysts [42,43]. The $\mathrm{Cu}(0.3)$ catalyst had the most serious activity decrease, maintaining $90 \% \mathrm{NO}$ conversion only between $250-425^{\circ} \mathrm{C}$. Furthermore, when the temperature was higher than $400{ }^{\circ} \mathrm{C}$, all the catalysts $\mathrm{NO}$ conversion rate dropped sharply, while for fresh sample it needed $500^{\circ} \mathrm{C}$. The $\mathrm{Cu}(0.2)$ catalyst had a similar activity like the $\mathrm{Cu}(0.3)$ catalyst between 100 and $425^{\circ} \mathrm{C}$ while it had a better performance in high-temperature range. This is due to the difference of $\mathrm{NH}_{3}$ oxidation ability of catalysts and will be discussed in detail below. The $\mathrm{N}_{2}$ selectivity of the three aged catalysts was slightly lower than that of the fresh samples, and the selectivity of the $\mathrm{Cu}(0.2) \mathrm{Mn}(0.1)$ sample was the best which was consistent with the activity.

After hydrothermal aging the deterioration of the catalysts performance in high temperature was more serious than that in the low temperature section, which indicated that the catalyst activity in the high temperature section was more sensitive to hydrothermal aging. This is because during hydrothermal aging parts of active species translate from $\mathrm{Cu}^{2+}$ or $\mathrm{Cu}(\mathrm{OH})^{+}$(two forms of $\mathrm{Cu}$ ions in the zeolite $[44,45])$ to $\mathrm{Cu}_{\mathrm{x}} \mathrm{O}_{\mathrm{y}}[20,23]$. These species have stronger oxidation than $\mathrm{Cu}$ ions and could oxidize the reducing agent $\mathrm{NH}_{3}$ through the non-selective oxidation as shown in Formula (1), which is the main side reaction in SCR [31]. 


$$
4 \mathrm{NH}_{3}+3 \mathrm{O}_{2}=2 \mathrm{~N}_{2}+6 \mathrm{H}_{2} \mathrm{O}
$$

Since in the standard SCR process the $\mathrm{NH}_{3}$ molecules and NO molecules are introduced at 1:1, the loss of reducing agent leads to a decrease in the NO conversion efficiency.

\section{2. $\mathrm{NH}_{3}$ and $\mathrm{NO}$ Oxidation Test}

$\mathrm{NH}_{3}$ oxidation capacity is an important indicator of SCR catalysts and the suitable oxidizability of the catalyst is pivotal to the SCR reaction $[31,37,43,46]$. Figure 3 shows the $\mathrm{NH}_{3}$ oxidation performance curve of the three catalysts before and after hydrothermal aging. It can be seen from Figure $3 \mathrm{a}$ that all the catalysts had weak $\mathrm{NH}_{3}$ oxidation ability below $200^{\circ} \mathrm{C}$ and when the temperature was higher than $250{ }^{\circ} \mathrm{C}$ the oxidation capacity started to rise rapidly, both $\mathrm{Cu}^{2+}$ and $\mathrm{Cu}(\mathrm{OH})^{+}$had a weak ability to oxidize $\mathrm{NH}_{3}$ to $\mathrm{N}_{2}$ at low temperatures [11]. As the temperature increased, the oxidation rate of $\mathrm{NH}_{3}$ rose continuously and reached $100 \%$ at $450{ }^{\circ} \mathrm{C}$. The $\mathrm{Cu}(0.2) \mathrm{Mn}(0.1)$ and $\mathrm{Cu}(0.2)$ catalysts had very similar oxidation activities, meaning that the Mn introduced by the co-exchange method did not cause excessive oxidation of $\mathrm{NH}_{3}$. Comparing Figure $3 \mathrm{a}$, b, we can see that the catalysts' $\mathrm{NH}_{3}$ oxidation ability increased after hydrothermal aging. Too high of an $\mathrm{NH}_{3}$ oxidation capacity leads to non-selective oxidation of reducing $\mathrm{NH}_{3}$, which is a major cause of reduced activity [20]. Among the samples, the $\mathrm{Cu}(0.3)$ sample had the highest $\mathrm{NH}_{3}$ oxidation promotion, indicating that samples with a high $\mathrm{Cu}$ content generated the most $\mathrm{Cu}_{\mathrm{x}} \mathrm{O}_{\mathrm{y}}$ species during hydrothermal aging, leading to a higher oxidation ability $[20,23,32,47]$. This is the reason why the $\mathrm{Cu}(0.3)$ catalyst performed the worst after hydrothermal aging, especially in the high temperature range.
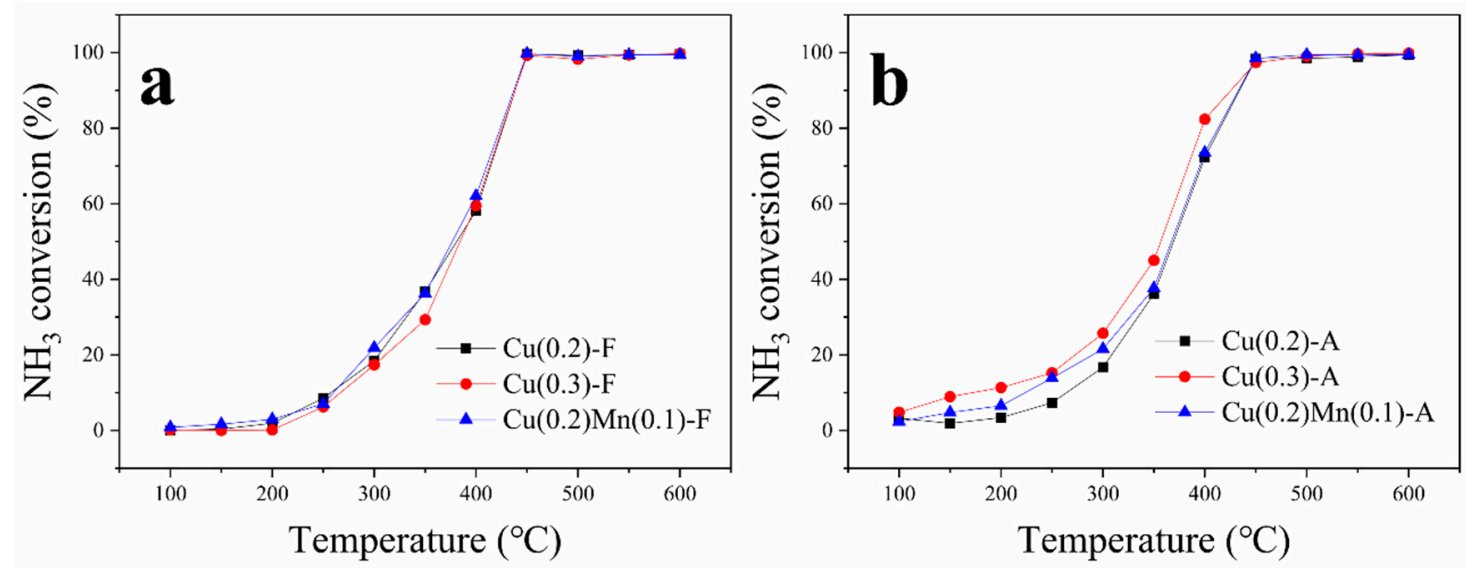

Figure 3. $\mathrm{NH}_{3}$ oxidation of catalysts before (a) and after (b) hydrothermal aging under a GHSV of $30,000 \mathrm{~h}^{-1}$.

NO oxidation is also relevant to better understand the SCR process $[48,49]$. As previously reported, isolated $\mathrm{Cu}$ species do not catalyze $\mathrm{NO}$ oxidation at low temperatures and $\mathrm{NO}$ oxidation only occurs when relatively stable O-bridged $\mathrm{Cu}$-dimers are formed $[35,49]$. Therefore, the oxidation activity of NO reflects the difficulty of forming $\mathrm{Cu}$-dimers in the catalyst. Figure $4 \mathrm{a}, \mathrm{b}$ shows the performance of NO oxidation of the three catalysts before and after hydrothermal aging. All the activity curves exhibited a volcanic-like shape $[20,35]$. With the increase of the temperature, the NO conversion rate rose to reach the highest at around $400{ }^{\circ} \mathrm{C}$ and then decreased. This is because when the temperature is higher than $400{ }^{\circ} \mathrm{C}, \mathrm{Cu}$ ions lose their complex small molecules and reduce their migration ability, which is not conducive to the formation of $\mathrm{Cu}$ dimers [44,50]. Furthermore, $\mathrm{Cu}$ dimers are more readily formed when there are more $\mathrm{Cu}$ ions, thus the $\mathrm{Cu}(0.3)$ sample had the highest $\mathrm{NO}$ oxidation capacity. Unlike for the $\mathrm{NH}_{3}$ oxidation process, the $\mathrm{Cu}(0.2)$ and $\mathrm{Cu}(0.2) \mathrm{Mn}(0.1)$ catalysts exhibited different catalytic activities in the NO oxidation reaction, though they had the same $\mathrm{Cu}$ content. This indicates that the addition of $\mathrm{Mn}$ species has an inhibitory effect on the migration of $\mathrm{Cu}$ ions to generate $\mathrm{Cu}$ dimers. 

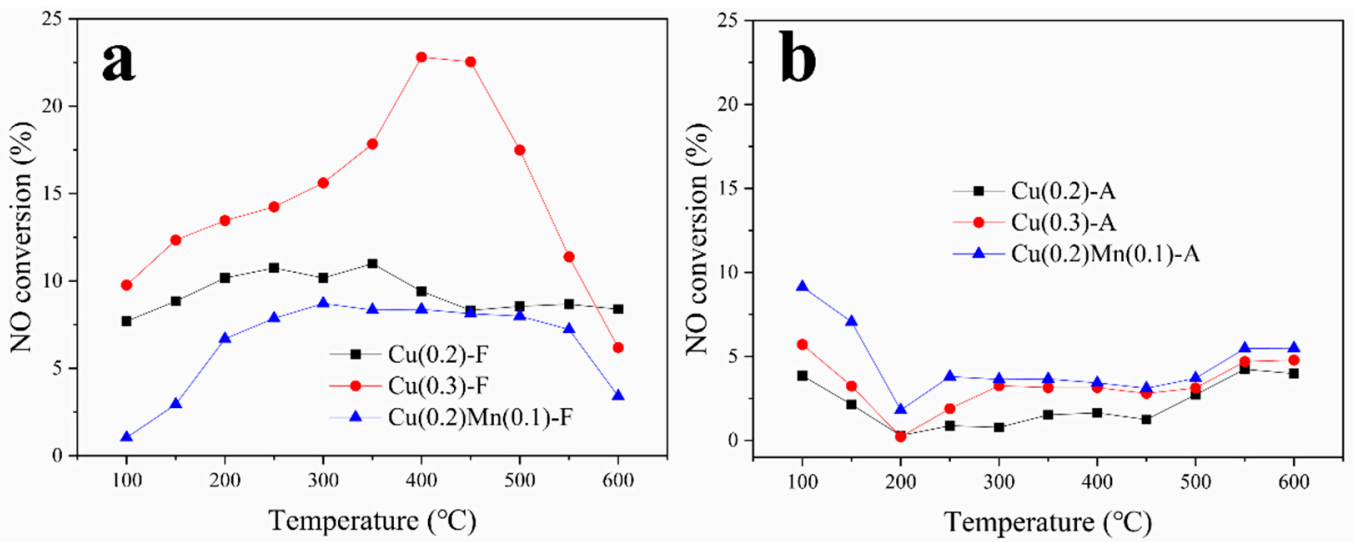

Figure 4. NO oxidation of catalysts before (a) and after (b) hydrothermal aging under a GHSV of $30,000 \mathrm{~h}^{-1}$.

One possible way to enhance the SCR activity at low temperatures is to oxidize some of the NO to $\mathrm{NO}_{2}$ so that a fast SCR occurs [47]. The reaction equation is presented below:

$$
\begin{gathered}
2 \mathrm{NO}+\mathrm{O}_{2}=2 \mathrm{NO}_{2} \\
\mathrm{NO}+\mathrm{NO}_{2}+2 \mathrm{NH}_{3}=2 \mathrm{~N}_{2}+3 \mathrm{H}_{2} \mathrm{O} .
\end{gathered}
$$

Our experiment proves that the introduction of Mn species by the co-exchange method in increasing the low-temperature activity of the catalyst does not follow the above mechanism and it was mainly caused by the promotion of Mn species. Figure $4 \mathrm{~b}$ shows the ability of the catalysts to catalyze the oxidation of $\mathrm{NO}$ was greatly decreased after hydrothermal aging. As discussed above, some of the isolated $\mathrm{Cu}^{2+}$ or $\mathrm{Cu}(\mathrm{OH})^{+}$species translate into $\mathrm{Cu}_{\mathrm{x}} \mathrm{O}_{\mathrm{y}}$, thus reducing the ability of catalysts to catalyze the oxidation of NO. Furthermore, the change of the NO oxidation capacity of the $\mathrm{Cu}(0.2) \mathrm{Mn}(0.1)$ catalyst after hydrothermal aging was minimal, which also indicates that this catalyst had the best resistance to hydrothermal aging.

\subsection{Temperature-Programmed Desorption with $\mathrm{NH}_{3}\left(\mathrm{NH}_{3}-\mathrm{TPD}\right)$}

Hydrothermal aging can seriously affect the acidity of the catalysts, which is an important factor affecting catalytic performance [48]. $\mathrm{NH}_{3}$-TPD experiments are often used to study the acidity of SSZ-13-based catalysts $[38,44]$. Figure 5 shows the $\mathrm{NH}_{3}$ desorption profiles of the samples before and after hydrothermal aging. The fresh samples show the presence of three desorption peaks, centered at about $150{ }^{\circ} \mathrm{C}$ (low temperature, LT), $300{ }^{\circ} \mathrm{C}$ (intermediate temperature, IT), and $475{ }^{\circ} \mathrm{C}$ (high temperature, HT). The LT peak corresponding to the weak adsorption of $\mathrm{NH}_{3}$ is assigned to physically adsorbed $\mathrm{NH}_{3}$ and $\mathrm{NH}_{3}$ adsorbed on weak acid sites [31,40,51]. The IT peak is attributed to $\mathrm{NH}_{3}$ desorption from Lewis (L) acid sites and the HT peak is due to strongly bound $\mathrm{NH}_{3}$, arising from protonated $\mathrm{NH}_{3}$ formed over the $\mathrm{B}$ acid sites [31,44,52]. Notably, the $\mathrm{Cu}(0.3)$ and the $\mathrm{Cu}(0.2) \mathrm{Mn}(0.1)$ samples presented similar $\mathrm{NH}_{3}$-TPD curves and the areas of every peak were also substantially uniform. This is because they have the same total ion exchange degree, so they have the same $\mathrm{L}$ acid sites. (the $\mathrm{L}$ sites are generated by metal elements entering the zeolite via the co-exchange method [44]) This also indicates that the adsorption strength of $\mathrm{NH}_{3}$ on $\mathrm{Cu}$ sites and $\mathrm{Mn}$ sites are similar. As for the $\mathrm{Cu}(0.2)$ sample, it was clear that the IT peak was smaller than that of others while the HT peak was a little bigger, as this sample had the lowest ion exchange degree. The LT peak areas of the three fresh samples were almost identical since they all had the same structure. 


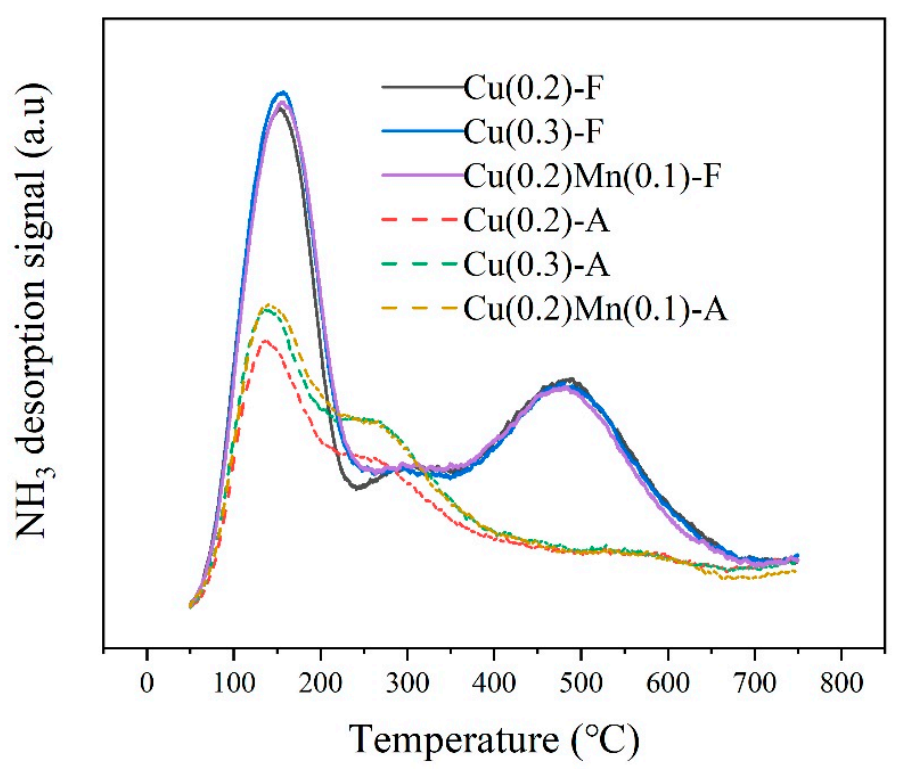

Figure 5. Temperature-programmed desorption with $\mathrm{NH}_{3}\left(\mathrm{NH}_{3}-\mathrm{TPD}\right)$ curves of catalysts before and after hydrothermal aging.

After hydrothermal aging, the $\mathrm{NH}_{3}$ adsorption capacity was greatly decreased and the desorption peaks at different temperatures were various. All the LT peaks had a reduced area, which indicates that the structure of the catalysts was damaged during the hydrothermal aging. The area reduction of the $\mathrm{Cu}(0.2)$ sample was the most obvious, indicating that its damage was the most serious. The peaks in the HT range almost completely disappeared, revealing the fact that the B acid sites are the most vulnerable during the hydrothermal aging [22]. Meanwhile, the destruction of B acid sites causes a chain reaction that leads to the damage of the catalysts $[23,53]$. Thus, this influence can be effectively improved by increasing the amount of ion exchange to reduce the amount of residual $\mathrm{B}$ acid sites. It is interesting to note that the amount of $\mathrm{NH}_{3}$ adsorbed at the IT segment increased. As mentioned above, $\mathrm{Cu}$ species change during hydrothermal aging. In addition to some of the isolate $\mathrm{Cu}$ species being converted to $\mathrm{Cu}_{x} \mathrm{O}_{y}$ clusters, some of the $\mathrm{Cu}(\mathrm{OH})^{+}$specie were converted to $\mathrm{Cu}^{2+}$ specie by the following equation:

$$
\mathrm{Cu}(\mathrm{OH})^{+}+\mathrm{H}^{+}=\mathrm{Cu}^{2+}+\mathrm{H}_{2} \mathrm{O} \text {. }
$$

This is because $\mathrm{Cu}$ species move to more thermodynamically stable sites at high temperatures $[44,50,52]$. At the same time, the curve of the $\mathrm{Cu}(0.2) \mathrm{Mn}(0.1)$ sample was similar to that of the $\mathrm{Cu}(0.3)$ sample, which suggests that the Mn species may also move to more thermodynamically stable sites at high temperatures, although more experiments are needed to clearly illustrate this problem. In summary, by the co-exchange method, increasing the total ion exchange degree can slow down the destruction of the acidity and structure.

\section{4. $X R D$}

In order to illustrate the changes of phase of the three catalysts before and after hydrothermal aging, their XRD patterns are shown in Figure 6. From Figure 6a, it can be seen that the XRD patterns of these fresh samples are similar to those reported in the literature for SSZ-13 materials [54]. The CHA phase (JCPDS file No.47-0762) was observed as the only crystalline phase in all samples. In each case, the diffraction intensities of the CHA phase of all samples had no difference. This indicates that the introduction of a small number of $\mathrm{Cu}$ and $\mathrm{Mn}$ elements does not influence the host structure. However, there was an obvious decrease of the diffraction intensities of the CHA phase for aged samples. This indicates that the crystal phase of the catalysts was damaged, resulting in a decrease in crystallinity. The maintained CHA phase can be used to explain the stable catalytic performance of $\mathrm{NH}_{3}$-SCR over 
these catalysts. It should be note that the degree of damage of the $\mathrm{Cu}(0.2)$ sample was more serious than that of $\mathrm{Cu}(0.2) \mathrm{Mn}(0.1)$ and $\mathrm{Cu}(0.3)$ samples. This means that the total ion exchange degree has a great influence on the stability. As mentioned above this is because the $\mathrm{B}$ acid sites are susceptible to damage during hydrothermal aging, while the higher exchange degree means that more $\mathrm{H}^{+}$sites in SSZ-13 can be replaced by metal ions, which effectively reduce the amount of residual B acid sites and enhance the stability of the catalysts $[22,23,55]$.
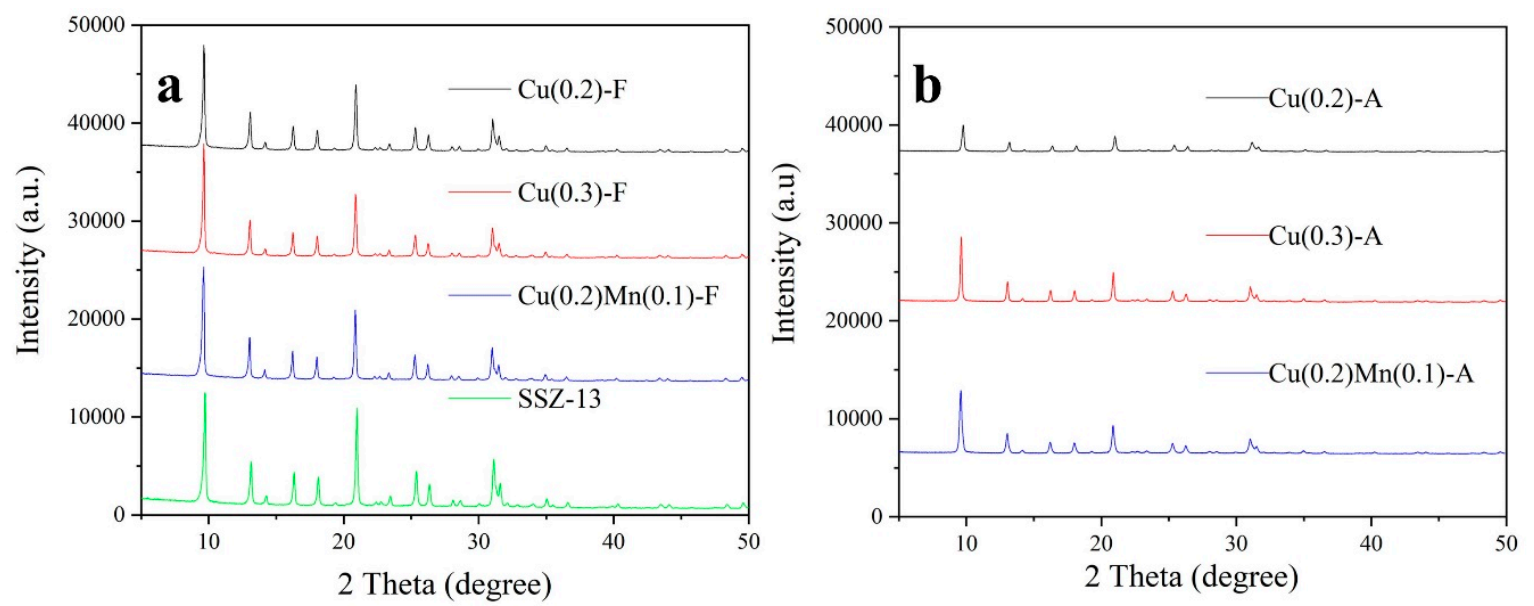

Figure 6. X-ray diffraction (XRD) patterns of catalysts before (a) and after (b) hydrothermal aging.

\subsection{NMR}

NMR is a commonly used method to characterize the changes in a zeolite framework structure. Figure $7 \mathrm{a}$. displays the ${ }^{27} \mathrm{Al}$ spectra acquired from hydrated, ambient samples before and after hydrothermal aging; the corresponding ${ }^{29} \mathrm{Si}$ NMR spectra are presented in Figure $7 \mathrm{~b}$. The features appearing at $58 \mathrm{ppm}$ are attributed to the framework $\mathrm{Al}$ (Alf) and the features appearing at $0 \mathrm{ppm}$ are attributed to the extra framework $\mathrm{Al}$ (EFAl) $[53,56,57]$. EFAl also has a certain catalytic activity and it can be seen from the spectrum that all three fresh samples contained almost no EFA1, thus eliminating the effect of the EFAl on the catalyst [40]. This is because the zeolite used in our experiments had a relatively high $\mathrm{Si} / \mathrm{Al}$ ratio (20), which is less prone to generate EFAl $[48,56]$. After hydrothermal aging, the Alf of every sample greatly decreased and the corresponding EFAL slightly increased, indicating that the dealumination of the zeolite skeleton occurred during hydrothermal aging-one of the main reasons leading to the destruction of the zeolite. Note that the reduction of the Alf was much larger than the increase of the EFAl. This is because some of $\mathrm{Al}$ can be converted to NMR-silent species $[23,45,58]$. Since the acidity of the zeolite is caused by the coordination imbalance of $\mathrm{Al}$ and $\mathrm{O}$ atoms, the loss of this portion of $\mathrm{Al}$ can result in a decrease in the total acidity of the zeolite. This is consistent with the $\mathrm{NH}_{3}$-TPD results. Among the three aged samples, the Alf of the $\mathrm{Cu}(0.2)$ was the most severely decreased while the changes of the $\mathrm{Cu}(0.3)$ and the $\mathrm{Cu}(0.2) \mathrm{Mn}(0.1)$ samples were much slighter. This is similar to the result of XRD and it means that increasing the total ion exchange degree of the zeolite can reduce the dealumination of the zeolite. The ${ }^{29} \mathrm{Si}$ NMR spectra show the same result. The features appearing at $-111 \mathrm{ppm}$ are attributed to $\mathrm{Si}(4 \mathrm{Si}, 0 \mathrm{Al})$ and the features appearing at $-105 \mathrm{ppm}$ are attributed to $\mathrm{Si}(3 \mathrm{Si}, 1 \mathrm{Al})[53,56,57]$. After hydrothermal aging, the $-105 \mathrm{ppm}$ feature declined while the -111 ppm feature rose, consistent with catalyst dealumination. It is clear that the $\mathrm{Cu}(0.2)$ sample had the most obvious change in peak intensity, also indicating that the degree of total ion exchange has an important influence on the structural stability of the catalysts. 

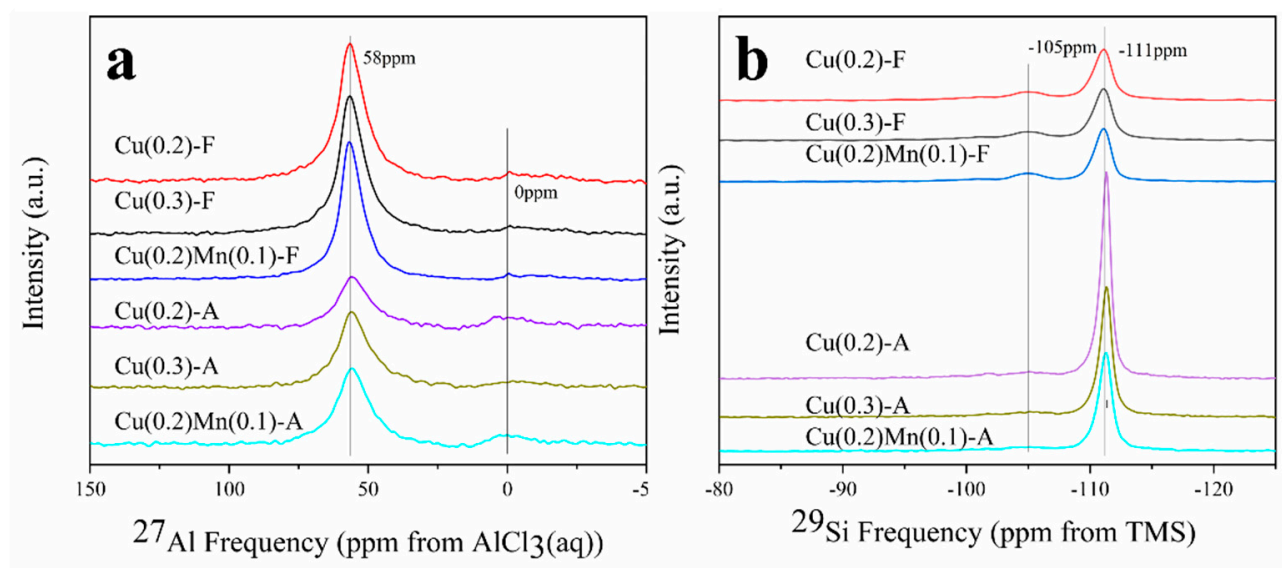

Figure 7. Solid-state ${ }^{27} \mathrm{Al}-\mathrm{NMR}$ spectra of the samples of catalysts before and after hydrothermal aging (a) and solid-state ${ }^{29} \mathrm{Si}-\mathrm{NMR}$ spectra of the samples of catalysts before and after hydrothermal aging (b).

From the discussion above, it can be seen that the total ion exchange plays an important role in the hydrothermal aging process of the catalyst. The content of residual $\mathrm{B}$ acid sites in the catalyst can be decreased, thus the acidity and structural damage of the catalyst during hydrothermal aging can be effectively reduced by increasing the total ion exchange degree of the catalysts. However, simply increasing the content of $\mathrm{Cu}^{2+}$ to increase the total ion exchange degree makes the catalyst prone to creating $\mathrm{Cu}_{\mathrm{x}} \mathrm{O}_{\mathrm{y}}$ species, as shown in the $\mathrm{NH}_{3}$ oxidation experiment, which leads to non-selective reduction reactions. Meanwhile, simply increasing the content of $\mathrm{Cu}^{2+}$ leads to the damage of the catalyst's pores during hydrothermal aging and this will be discussed in detail below.

\subsection{Physical Properties}

Figure 8 shows the SEM images of the fresh and aged samples. The fresh samples exhibited a cube shape, which is the typical morphology of SSZ-13 and the average particle size of the catalyst was about $200 \mathrm{~nm}$. In addition, the images indicate that the catalysts showed a perfect degree of crystallization which is in accordance with the XRD results. After hydrothermal aging, most of the particles still retained the structure of the cube. That means that the structure of the catalysts was partially destroyed after hydrothermal aging while its basic structure ca=ould be maintained and this consistent with our findings above. It is clear from the mapping pictures shown in Figure S5 that the $\mathrm{Cu}$ element and $\mathrm{Mn}$ element of the $\mathrm{Cu}(0.2) \mathrm{Mn}(0.1)$ sample were quite evenly distributed.

Figure 9 depicts the curves of the micropores and mesopores before and after the hydrothermal aging of the catalysts. In the micropores (diameter $<2 \mathrm{~nm}$ ), as Figure $9 \mathrm{a}, \mathrm{c}, \mathrm{e}$ show, the pores of the samples were concentrated at about $0.38 \mathrm{~nm}$, which is a perfect reflection of the theoretical pore size of the CHA zeolite. It can be seen that after hydrothermal aging, the $\mathrm{Cu}(0.3)$ sample suffered the largest reduction of microporous pores, while the $\mathrm{Cu}(0.2) \mathrm{Mn}(0.1)$ sample exhibited the least reduction. Meanwhile, as shown in the mesoporous portion, the amount of mesopores (2 $50 \mathrm{~nm}$ as shown in Figure $9 b, d, f)$ increased after hydrothermal aging. Consistent with the change of micropores, the increase of the mesopores of the $\mathrm{Cu}(0.3)$ sample was the largest while there was almost no difference in the mesopores of the $\mathrm{Cu}(0.2) \mathrm{Mn}(0.1)$ sample. This is also important evidence for the pore destruction of the catalysts.

The destruction of the pore structure of the catalyst is due to the formation and migration of $\mathrm{Cu}_{\mathrm{x}} \mathrm{O}_{\mathrm{y}}$, with a larger than the primary pore size $(0.38 \mathrm{~nm})$ of SSZ-13 [23]. The results indicate that addition of $\mathrm{Mn}$ species can slow down the formation of $\mathrm{Cu}_{\mathrm{x}} \mathrm{O}_{\mathrm{y}}$ and alleviate the damage of the pore structure of the catalysts. The Brunauer-Emmett-Teller (BET) specific surface area embedded in Figure 9 also reflects the extent to which the catalysts were affected by hydrothermal aging. All the samples before hydrothermal aging had similar specific surface areas and their slight differences may have been due to subtle differences in the preparation process. After hydrothermal aging, the specific surface area of 
the $\mathrm{Cu}(0.2) \mathrm{Mn}(0.1)$ was the largest, and that of the $\mathrm{Cu}(0.3)$ was the smallest also revealing that the addition of Mn species greatly slowed down the damage of the catalyst during hydrothermal aging.

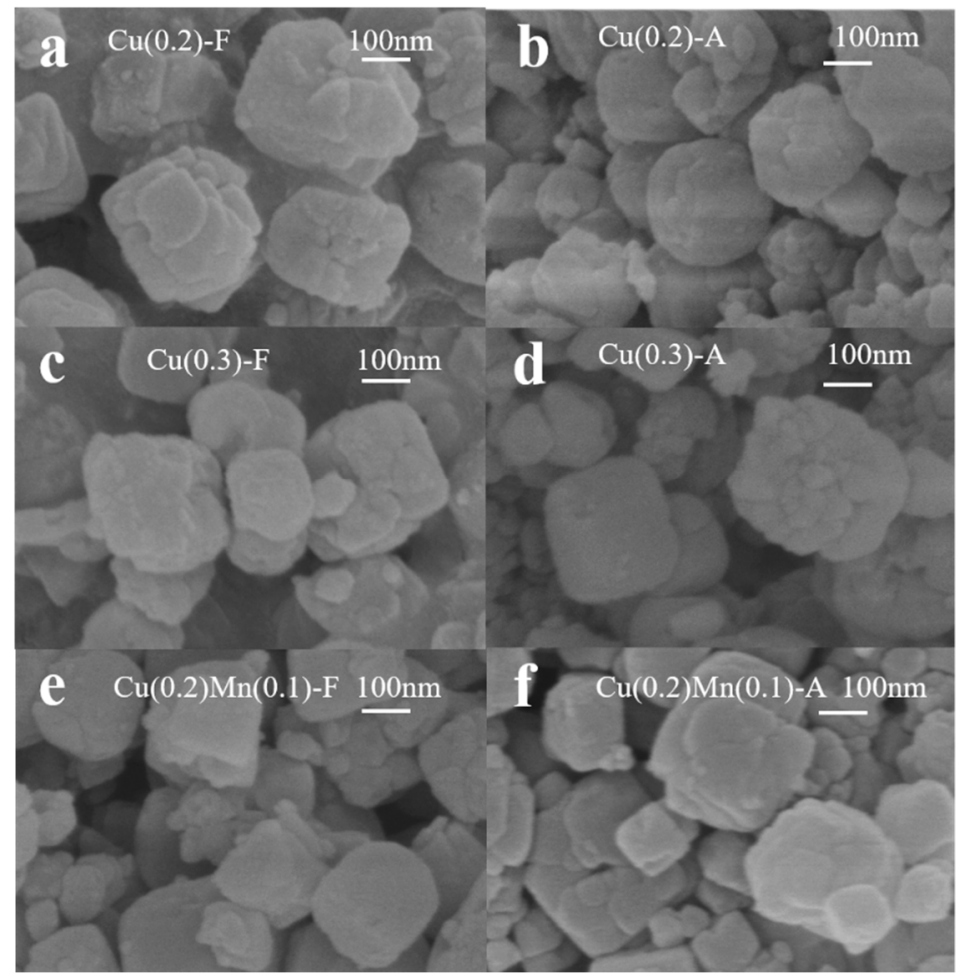

Figure 8. SEM images of catalysts before $(\mathbf{a}, \mathbf{c}, \mathbf{e})$ and after $(\mathbf{b}, \mathbf{d}, \mathbf{f})$ hydrothermal aging.
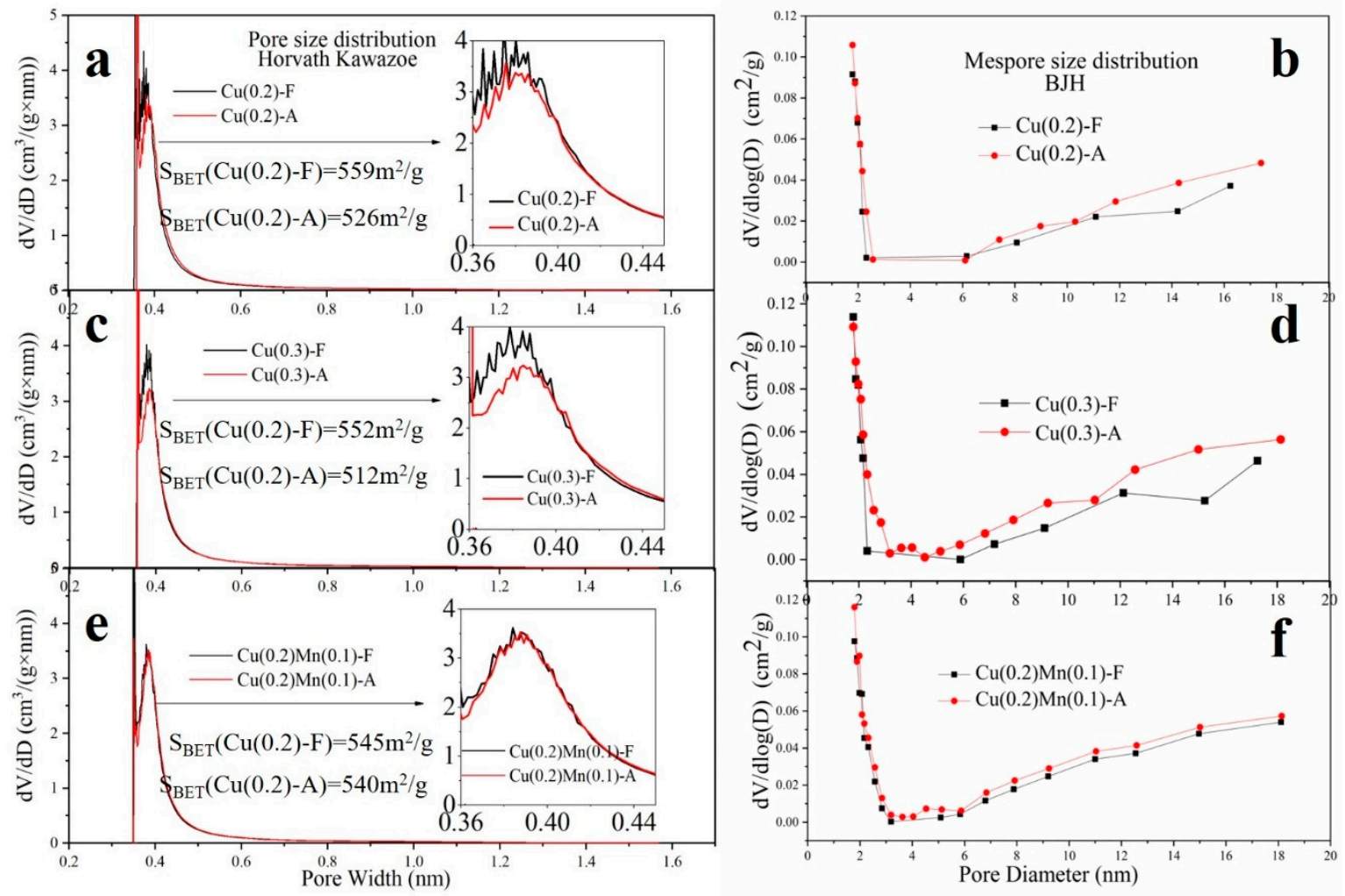

Figure 9. Micropore size distributions of catalysts before and after hydrothermal aging $(\mathbf{a}, \mathbf{c}, \mathbf{e})$ and mesopore size distributions before and after hydrothermal aging $(\mathbf{b}, \mathbf{d}, \mathbf{f})$. 


\section{Materials and Methods}

\subsection{Catalyst Preparation}

The SSZ-13 zeolite was prepared using a hydrothermal method with the N, N, N-trimethyl-11-adamantammonium hydroxide (TMAdaOH) serving as a structure-directing agent (SDA). Firstly, $4 \mathrm{~g}$ of $\mathrm{NaAlO}_{2}$ and $0.2 \mathrm{~g} \mathrm{NaOH}$ were added to $20 \mathrm{~g}$ of deionized water and the mixture was stirred at room temperature for $30 \mathrm{~min}$. Then $6 \mathrm{~g}$ SDA was added to the solution and $20 \mathrm{~g}$ of silica sol (40\%) was added dropwise with constant stirring. After stirring for $4 \mathrm{~h}$, the sol was transferred into Teflon-lined autoclaves and reacted at $160{ }^{\circ} \mathrm{C}$ for $96 \mathrm{~h}$. After that, the product was separated from the mother liquid via centrifugation and washing with deionized water three times. Finally, the solid powder was dried overnight at $120^{\circ} \mathrm{C}$, then calcined at $390{ }^{\circ} \mathrm{C}$ for 1 hour and then heated at $2^{\circ} \mathrm{C} / \mathrm{min}$ to $550{ }^{\circ} \mathrm{C}$ and held for $6 \mathrm{~h}$.

The Cu-SSZ-13 catalysts were prepared using a standard two-step solution ion exchange method. First, the obtained Na-SSZ-13 was exchanged three times with a $0.1 \mathrm{M}$ solution of $\mathrm{NH}_{4} \mathrm{NO}_{3}$ at $80{ }^{\circ} \mathrm{C}$ for $12 \mathrm{~h}$ to generate the $\mathrm{NH}_{4}-\mathrm{SSZ}-13$. Then the $\mathrm{Cu}-\mathrm{SSZ}-13$ was obtained by exchanging with a $0.1 \mathrm{M}$ solution of $\mathrm{Cu}\left(\mathrm{NO}_{3}\right)$ and the $\mathrm{pH}$ of the solution was adjusted to 3 by adding dilute $\mathrm{HNO}_{3}$ solution (10\%). Similarly, $\mathrm{Cu}-\mathrm{Mn}-\mathrm{SSZ}-13$ samples with different $\mathrm{Mn} / \mathrm{Cu}$ ratios were prepared by ion exchange under a mixed solution of $\mathrm{Cu}\left(\mathrm{NO}_{3}\right)_{2}$ and $\mathrm{Mn}\left(\mathrm{NO}_{3}\right)_{2}$ (co-exchange method). By changing the $\mathrm{Mn} / \mathrm{Cu}$ ratio in the solution, $\mathrm{Cu}-\mathrm{Mn}-\mathrm{SSZ}-13$ catalysts with different ion exchange degrees were obtained and the content of $\mathrm{Cu}$ and $\mathrm{Mn}$ was measured by inductively coupled plasma atomic emission spectroscopy (ICP-AES). The ion exchange degree was calculated by Formula 5 and the results are shown in Table 1, at the same time, the $\mathrm{Si} / \mathrm{Al}$ molar ratio of all samples was 20. Finally, all the solid powders were calcined in air at $550{ }^{\circ} \mathrm{C}$ for $6 \mathrm{~h}$.

$$
\text { ion exchange degree }=\left(\frac{\text { mole } \mathrm{Cu}(\text { or } \mathrm{Mn})}{\text { mole } \mathrm{Al}}\right) \times 200 \%
$$

The $\mathrm{Cu}-\mathrm{Mn}-\mathrm{SSZ}-13$ samples with different molar ratio of $\mathrm{Mn} / \mathrm{Cu}$ catalysts were named as $\mathrm{Cu}(\mathrm{x}) \mathrm{Mn}(\mathrm{y})-\mathrm{F}(\mathrm{A})$, in which $\mathrm{x}$ and $\mathrm{y}$ represents the ion exchange degree of $\mathrm{Cu}$ and $\mathrm{Mn}$ elements, and fresh or hydrothermally aged samples were distinguished by the suffix letter F or A

\subsection{Catalyst Characterization}

The catalyst structures were characterized by powder X-ray diffraction (XRD) on a Rigaku D/MAX 2550 diffractometer (Karlsruhe, Germany) equipped with $\mathrm{Cu} K \alpha(40 \mathrm{kV}, 40 \mathrm{~mA})$ radiation $(\lambda=1.540598 \AA)$ using a scan range from 5 to $50^{\circ}$ with a scan step of $8^{\circ} \mathrm{min}^{-1}$.

The element contents were determined by inductively coupled plasma atomic emission spectroscopy (ICP-AES) (Massachusetts, USA).

Temperature programmed reduction with hydrogen $\left(\mathrm{H}_{2}-\mathrm{TPR}\right)$ experiments were performed on a Micromeritics Auto Chem II chemisorption analyzer (Norcross, USA). In each experiment, $100 \mathrm{mg}$ of sample was loaded into a quartz reactor and then pretreated in He $(50 \mathrm{~mL} / \mathrm{min})$ at $400{ }^{\circ} \mathrm{C}$ for $2 \mathrm{~h}$. The reduction of the sample was carried out from $50{ }^{\circ} \mathrm{C}$ to $600{ }^{\circ} \mathrm{C}$ under a flow of $10 \% \mathrm{H}_{2} / \mathrm{Ar}$ $(50 \mathrm{~mL} / \mathrm{min})$ at $10{ }^{\circ} \mathrm{C} / \mathrm{min}$.

Low-temperature $\mathrm{N}_{2}$ adsorption-desorption analysis was carried out at $77 \mathrm{~K}$ using a Micromeritics ASAP 2460 instrument (Norcross, USA). Before the measurement, all samples were dried overnight at $120{ }^{\circ} \mathrm{C}$, then treated under vacuum at $90{ }^{\circ} \mathrm{C}$ for $3 \mathrm{~h}$ and finally treated under vacuum at $250{ }^{\circ} \mathrm{C}$ for $6 \mathrm{~h}$. The specific surface area, mesoporous and micropore size were determined by the Brunauer-Emmett-Teller (BET) method, Barrett-Joyner-Halenda (BJH) method and Horvath-Kawazoe (H-K) method, respectively.

Temperature programmed desorption with $\mathrm{NH}_{3}\left(\mathrm{NH}_{3}-\mathrm{TPD}\right)$ tests were conducted on a Micromeritics Auto Chem II chemisorption analyzer (Norcross, USA). The powder samples were about $100 \mathrm{mg}$ and before testing the powder samples needed to be pre-treated with $\mathrm{He}$ for $2 \mathrm{~h}$ at $400{ }^{\circ} \mathrm{C}$, then 
cooled to $50{ }^{\circ} \mathrm{C}$. After that, the samples were exposed to $2 \% \mathrm{NH}_{3} / \mathrm{He}$ for $2 \mathrm{~h}$ at $50{ }^{\circ} \mathrm{C}$, followed by a purge in $\mathrm{He}$ at $50^{\circ} \mathrm{C}$ for $2 \mathrm{~h}$. Finally, the TPD data were obtained by heating the samples from $50{ }^{\circ} \mathrm{C}$ to $750{ }^{\circ} \mathrm{C}$ with a heating rate of $10^{\circ} \mathrm{C} / \mathrm{min}$ under pure $\mathrm{He}(100 \mathrm{~mL} / \mathrm{min})$.

Solid-state nuclear magnetic resonance (NMR) analysis of the samples was conducted on an Infinityplus 300 instrument (California, USA). About $0.1 \mathrm{~g}$ of the samples were transferred into a gastight rotor, and the rotor mounted into the NMR spectrometer. ${ }^{27} \mathrm{Al}$ chemical shifts were reported relative to a $0.1 \mathrm{M}$ aqueous $\mathrm{AlCl}_{3}$ solution and ${ }^{29} \mathrm{Si}$ chemical shifts were reported relative to a $\mathrm{Si}\left(\mathrm{CH}_{3}\right)_{4}$ standard.

Scanning electron microscopy (SEM) and energy dispersive spectroscopy (EDS) was carried out on Hitachi S-4800 instrument (Tokyo, Japan) using a $3.0 \mathrm{kV}$ electron beam and before test, all samples were sprayed with gold for $50 \mathrm{~s}$.

\subsection{Catalytic Activity and Hydrothermal Stability Measurements}

$\mathrm{NH}_{3}$-SCR experiments were performed in a fixed bed reactor with a $12 \mathrm{~mm}$ inner diameter. The catalysts were crushed and sieved into 40-60 mesh before the catalytic measurements. The reaction conditions were $500 \mathrm{ppm} \mathrm{NO}, 500 \mathrm{ppm} \mathrm{NH}_{3}, 5 \mathrm{vol} \% \mathrm{O}_{2}, 2.5 \mathrm{vol} \% \mathrm{H}_{2} \mathrm{O}$, and the gas hourly space velocity $(\mathrm{GHSV})=30,000 \mathrm{~h}^{-1}$. The concentrations of $\mathrm{NH}_{3}, \mathrm{NO}, \mathrm{NO}_{2}$, and $\mathrm{N}_{2} \mathrm{O}$ were measured by a Fourier-transform infrared (FTIR) spectrometer (Thermo Nicolet IS 10).

The $\mathrm{NH}_{3}$ and $\mathrm{NO}$ oxidation reactions were also conducted under the same conditions except that, in $\mathrm{NH}_{3}$ oxidation, the $\mathrm{NO}$ feed was stopped while in the $\mathrm{NO}$ oxidation, the $\mathrm{NH}_{3}$ feed was stopped.

The hydrothermal aging experiment was carried out in a vacuum tube furnace. The aging gas components included $75 \% \mathrm{~N}_{2}, 15 \% \mathrm{O}_{2}$ and $10 \% \mathrm{H}_{2} \mathrm{O}$. The aging temperature was $800{ }^{\circ} \mathrm{C}$ and the GHSV $=30,000 \mathrm{~h}^{-1}$.

The conversion of $\mathrm{NO}$ and $\mathrm{NH}_{3}$ and the selectivity of $\mathrm{N}_{2}$ were calculated by the following equations:

$$
\begin{gathered}
\text { NO conversion }=\left(1-\frac{\mathrm{NO}_{\text {outlet }}}{\mathrm{NO}_{\text {inlet }}}\right) \times 100 \% \\
\mathrm{NH}_{3} \text { conversion }=\left(1-\frac{\mathrm{NH}_{3 \text { outlet }}}{\mathrm{NH}_{3 \text { inlet }}}\right) \times 100 \% \\
\mathrm{~N}_{2} \text { selectivity }=\frac{\mathrm{NH}_{3 \text { inlet }}+\mathrm{NO}_{\text {inlet }}-\mathrm{NH}_{3 \text { outlet }}-\mathrm{NO}_{\text {outlet }}-2 \mathrm{~N}_{2} \mathrm{O}_{\text {outlet }}-\mathrm{NO}_{2_{\text {outlet }}}}{\mathrm{NH}_{3 \text { inlet }}+\mathrm{NO}_{\text {inlet }}-\mathrm{NH}_{3 \text { outlet }}-\mathrm{NO}_{\text {outlet }}} \times 100 \% .
\end{gathered}
$$

\section{Conclusions}

In our study, it was found that Mn was a promising promoter and changed the structure, stability and performance of Cu-SSZ-13 catalysts. Therefore, some points can be put forward as follows:

(1) Several Cu-Mn-SSZ-13 catalysts with different Mn/Cu molar ratio and well-crystallized SSZ-13 CHA structure were prepared by ion-exchange of $\mathrm{Mn}$ and $\mathrm{Cu}$ into SSZ-13 together.

(2) $\mathrm{The} \mathrm{Cu}(0.2) \mathrm{Mn}(0.1)-\mathrm{SSZ}-13$ catalyst has high reactivity at low-temperature and strong resistance to hydrothermal aging. It presents a more than $90 \% \mathrm{NO}$ conversion in a wide temperature range $\left(175-525^{\circ} \mathrm{C}\right)$ and can still maintain more than $90 \%$ NO conversion in a temperature range of $180-475$ ${ }^{\circ} \mathrm{C}$ after rigorous hydrothermal aging.

(3) The high total ion exchange degree is beneficial in reducing the residual B acid sites and thus decreasing the destruction of SSZ-13 phase and inhibiting the dealumination of the skeleton during the hydrothermal process.

(4) The moderate addition of Mn to Cu-SSZ-13 contribute to the high $\mathrm{NH}_{3}$-SCR activity and inhibits the aggregation of $\mathrm{Cu}$ species and the pore destruction of the catalyst during hydrothermal aging thus achieving excellent hydrothermal stability.

Supplementary Materials: The following are available online http://www.mdpi.com/2073-4344/9/5/455/s1, Figure S1: XRD pattern of the synthetic SSZ-13 powder, Figure S2: SEM images of the synthetic SSZ-13 powder, Figure S3: XRD patterns of different $\mathrm{Cu}-\mathrm{Mn}-\mathrm{SSZ}-13$ catalysts, Figure S4: Temperature programmed 
reduction with hydrogen $\left(\mathrm{H}_{2}-\mathrm{TPR}\right)$ curves of different $\mathrm{Cu}-\mathrm{Mn}-\mathrm{SSZ}-13$ catalysts, Figure S5: Elemental mapping images of fresh and aged $\mathrm{Cu}(0.2) \mathrm{Mn}(0.1)$ catalysts.

Author Contributions: C.S. and Y.L. conceived and designed the experiments; C.S., Z.L. and K.L. performed the experiments and contributed reagents and materials; C.S. wrote the manuscript; L.Z. and Y.L. checked and corrected the manuscript.

Funding: This research was funded by National Natural Science Foundation of China grant number [21776214].

Conflicts of Interest: The authors declare no conflict of interest.

\section{References}

1. Zhang, R.; Liu, N.; Lei, Z.; Chen, B. Selective Transformation of Various Nitrogen-Containing Exhaust Gases toward $\mathrm{N}_{2}$ over Zeolite Catalysts. Chem. Rev. 2016, 116, 3658-3721. [CrossRef]

2. Ruggeri, M.P.; Luo, J.; Nova, I.; Tronconi, E.; Kamasamudram, K.; Yezerets, A. Novel method of ammonium nitrate quantification in SCR catalysts. Catal. Today 2018, 307, 48-54. [CrossRef]

3. Xu, J.; Chen, G.; Guo, F.; Xie, J. Development of wide-temperature vanadium-based catalysts for selective catalytic reducing of $\mathrm{NO}_{x}$ with ammonia: Review. Chem. Eng. J. 2018, 353, 507-518. [CrossRef]

4. Hammershøi, P.S.; Jangjou, Y.; Epling, W.S.; Jensen, A.D.; Janssens, T.V.W. Reversible and irreversible deactivation of $\mathrm{Cu}-\mathrm{CHA} \mathrm{NH} \mathrm{NH}_{3}-\mathrm{SCR}$ catalysts by $\mathrm{SO}_{2}$ and $\mathrm{SO}_{3}$. Appl. Catal. B Environ. 2018, 226, 38-45. [CrossRef]

5. Beale, A.M.; Gao, F.; Lezcano-Gonzalez, I.; Peden, C.H.F.; Szanyi, J. Recent advances in automotive catalysis for $\mathrm{NO}_{x}$ emission control by small-pore microporous materials. Chem. Soc. Rev. 2015, 44, 7371-7405. [CrossRef]

6. Xin, Y.; Li, Q.; Zhang, Z. Zeolitic Materials for DeNO ${ }_{x}$ Selective Catalytic Reduction. ChemCatChem 2018, 10, 29-41. [CrossRef]

7. Clemens, A.K.S.; Shishkin, A.; Carlsson, P.A.; Skoglundh, M.; Martínez-Casado, F.J.; Matěj, Z.; Balmes, O.; Härelind, H. Reaction-driven Ion Exchange of Copper into Zeolite SSZ-13. ACS Catal. 2015, 5, 6209-6218. [CrossRef]

8. Borfecchia, E.; Beato, P.; Svelle, S.; Olsbye, U.; Lamberti, C.; Bordiga, S. Cu-CHA-A model system for applied selective redox catalysis. Chem. Soc. Rev. 2018, 47, 8097-8133. [CrossRef]

9. Wijayanti, K.; Xie, K.; Kumar, A.; Kamasamudram, K.; Olsson, L. Effect of gas compositions on $\mathrm{SO}_{2}$ poisoning over Cu/SSZ-13 used for $\mathrm{NH}_{3}$-SCR. Appl. Catal. B Environ. 2017, 219, 142-154. [CrossRef]

10. Granger, P.; Parvulescu, V.I. Catalytic $\mathrm{NO}_{x}$ Abatement Systems for Mobile Sources: From Three-Way to Lean Burn after-Treatment Technologies. Chem. Rev. 2011, 111, 3155-3207. [CrossRef]

11. Gao, F.; Walter, E.D.; Karp, E.M.; Luo, J.; Tonkyn, R.G.; Kwak, J.H.; Szanyi, J.; Peden, C.H.F. Structure-activity relationships in $\mathrm{NH}_{3}$-SCR over Cu-SSZ-13 as probed by reaction kinetics and EPR studies. J. Catal. 2013, 300, 20-29. [CrossRef]

12. Schmidt, J.E.; Oord, R.; Guo, W.; Poplawsky, J.D.; Weckhuysen, B.M. Nanoscale tomography reveals the deactivation of automotive copper-exchanged zeolite catalysts. Nat. Commun. 2017, 8, 1666. [CrossRef]

13. Marberger, A.; Petrov, A.W.; Steiger, P.; Elsener, M.; Kröcher, O.; Nachtegaal, M.; Ferri, D. Time-resolved copper speciation during selective catalytic reduction of NO on Cu-SSZ-13. Nat. Catal. 2018, 1, 221-227. [CrossRef]

14. Zhao, Z.; Yu, R.; Zhao, R.; Shi, C.; Gies, H.; Xiao, F.-S.; De Vos, D.; Yokoi, T.; Bao, X.; Kolb, U.; et al. $\mathrm{Cu}$-exchanged Al-rich SSZ-13 zeolite from organotemplate-free synthesis as $\mathrm{NH}_{3}$-SCR catalyst: Effects of $\mathrm{Na}^{+}$ions on the activity and hydrothermal stability. Appl. Catal. B Environ. 2017, 217, 421-428. [CrossRef]

15. Jangjou, Y.; Do, Q.; Gu, Y.; Lim, L.-G.; Sun, H.; Wang, D.; Kumar, A.; Li, J.; Grabow, L.C.; Epling, W.S. Nature of $\mathrm{Cu}$ Active Centers in Cu-SSZ-13 and Their Responses to $\mathrm{SO}_{2}$ Exposure. ACS Catal. 2018, 8, 1325-1337. [CrossRef]

16. Kwak, J.H.; Tonkyn, R.G.; Kim, D.H.; Szanyi, J.; Peden, C.H.F. Excellent activity and selectivity of Cu-SSZ-13 in the selective catalytic reduction of $\mathrm{NO}_{x}$ with $\mathrm{NH}_{3}$. J. Catal. 2010, 275, 187-190. [CrossRef]

17. Forzatti, P.; Nova, I.; Tronconi, E. Enhanced $\mathrm{NH}_{3}$ Selective Catalytic Reduction for $\mathrm{NO}_{\mathrm{x}}$ Abatement. Angew. Chem. Int. Ed. 2009, 48, 8366-8368. [CrossRef]

18. Liu, C.; Shi, J.-W.; Gao, C.; Niu, C. Manganese oxide-based catalysts for low-temperature selective catalytic reduction of $\mathrm{NO}_{x}$ with $\mathrm{NH}_{3}$ : A review. Appl. Catal. A Gen. 2016, 522, 54-69. [CrossRef]

19. Wang, D.; Jangjou, Y.; Liu, Y.; Sharma, M.K.; Luo, J.; Li, J.; Kamasamudram, K.; Epling, W.S. A comparison of hydrothermal aging effects on $\mathrm{NH}_{3}-\mathrm{SCR}$ of $\mathrm{NO}_{x}$ over Cu-SSZ-13 and Cu-SAPO-34 catalysts. Appl. Catal. B Environ. 2015, 165, 438-445. [CrossRef] 
20. Schmieg, S.J.; Oh, S.H.; Kim, C.H.; Brown, D.B.; Lee, J.H.; Peden, C.H.F.; Kim, D.H. Thermal durability of $\mathrm{Cu}-\mathrm{CHA} \mathrm{NH} \mathrm{N}_{3}-\mathrm{SCR}$ catalysts for diesel $\mathrm{NO}_{x}$ reduction. Catal. Today 2012, 184, 252-261. [CrossRef]

21. Kim, Y.J.; Lee, J.K.; Min, K.M.; Hong, S.B.; Nam, I.-S.; Cho, B.K. Hydrothermal stability of CuSSZ13 for reducing $\mathrm{NO}_{x}$ by $\mathrm{NH}_{3}$. J. Catal. 2014, 311, 447-457. [CrossRef]

22. Gao, F.; Wang, Y.; Washton, N.M.; Kollár, M.; Szanyi, J.; Peden, C.H.F. Effects of Alkali and Alkaline Earth Cocations on the Activity and Hydrothermal Stability of Cu/SSZ-13 $\mathrm{NH}_{3}-$ SCR Catalysts. ACS Catal. 2015, 5, 6780-6791. [CrossRef]

23. Song, J.; Wang, Y.; Walter, E.D.; Washton, N.M.; Mei, D.; Kovarik, L.; Engelhard, M.H.; Prodinger, S.; Wang, Y.; Peden, C.H.F.; et al. Toward Rational Design of Cu/SSZ-13 Selective Catalytic Reduction Catalysts: Implications from Atomic-Level Understanding of Hydrothermal Stability. ACS Catal. 2017, 7, 8214-8227. [CrossRef]

24. Liu, Q.; Fu, Z.; Ma, L.; Niu, H.; Liu, C.; Li, J.; Zhang, Z. MnO -CeO2 supported on Cu-SSZ-13: A novel SCR catalyst in a wide temperature range. Appl. Catal. A Gen. 2017, 547, 146-154. [CrossRef]

25. Boningari, T.; Ettireddy, P.R.; Somogyvari, A.; Liu, Y.; Vorontsov, A.; McDonald, C.A.; Smirniotis, P.G. Influence of elevated surface texture hydrated titania on Ce-doped $\mathrm{Mn} / \mathrm{TiO}_{2}$ catalysts for the low-temperature SCR of NO x under oxygen-rich conditions. J. Catal. 2015, 325, 145-155. [CrossRef]

26. Pappas, D.K.; Boningari, T.; Boolchand, P.; Smirniotis, P.G. Novel manganese oxide confined interweaved titania nanotubes for the low-temperature Selective Catalytic Reduction (SCR) of $\mathrm{NO}_{x}$ by $\mathrm{NH}_{3}$. J. Catal. 2016, 334, 1-13. [CrossRef]

27. Meng, D.; Xu, Q.; Jiao, Y.; Guo, Y.; Guo, Y.; Wang, L.; Lu, G.; Zhan, W. Spinel structured $\mathrm{Co}_{a} \mathrm{Mn}_{\mathrm{b}} \mathrm{O}_{\mathrm{x}}$ mixed oxide catalyst for the selective catalytic reduction of $\mathrm{NO}_{x}$ with $\mathrm{NH}_{3}$. Appl. Catal. B Environ. 2018, 221, 652-663. [CrossRef]

28. Shen, Q.; Zhang, L.; Sun, N.; Wang, H.; Zhong, L.; He, C.; Wei, W.; Sun, Y. Hollow $\mathrm{MnO}_{\mathrm{x}}-\mathrm{CeO}_{2}$ mixed oxides as highly efficient catalysts in NO oxidation. Chem. Eng. J. 2017, 322, 46-55. [CrossRef]

29. Cheng, M.; Jiang, B.; Yao, S.; Han, J.; Zhao, S.; Tang, X.; Zhang, J.; Wang, T. Mechanism of $\mathrm{NH}_{3}$ Selective Catalytic Reduction Reaction for $\mathrm{NO}_{\mathrm{x}}$ Removal from Diesel Engine Exhaust and Hydrothermal Stability of $\mathrm{Cu}-\mathrm{Mn} /$ Zeolite Catalysts. J. Phys. Chem. C 2017, 122, 455-464. [CrossRef]

30. Liu, B.; Zhou, R.; Bu, N.; Wang, Q.; Zhong, S.; Wang, B.; Hidetoshi, K. Room-temperature ionic liquids modified zeolite SSZ-13 membranes for $\mathrm{CO}_{2} / \mathrm{CH}_{4}$ separation. J. Membr. Sci. 2017, 524, 12-19. [CrossRef]

31. Wang, D.; Gao, F.; Peden, C.H.F.; Li, J.; Kamasamudram, K.; Epling, W.S. Selective Catalytic Reduction of $\mathrm{NO}_{x}$ with $\mathrm{NH}_{3}$ over a Cu-SSZ-13 Catalyst Prepared by a Solid-State Ion-Exchange Method. ChemCatChem 2014, 6, 1579-1583. [CrossRef]

32. Ye, Y.; Shen, F.; Wang, H.; Chen, R. SSZ-13-supported manganese oxide catalysts for low temperature selective catalytic reduction of $\mathrm{NO}_{x}$ by $\mathrm{NH}_{3}$. J. Chem. Sci. 2017, 129, 765-774. [CrossRef]

33. Li, J.; Chang, H.; Ma, L.; Hao, J.; Yang, R.T. Low-temperature selective catalytic reduction of $\mathrm{NO}_{x} \mathrm{with}^{\mathrm{NH}} \mathrm{H}_{3}$ over metal oxide and zeolite catalysts-A review. Catal. Today 2011, 175, 147-156. [CrossRef]

34. Shan, W.; Song, H. Catalysts for the selective catalytic reduction of $\mathrm{NO}_{x}$ with $\mathrm{NH}_{3}$ at low temperature. Catal. Sci. Technol. 2015, 5, 4280-4288. [CrossRef]

35. Gao, F.; Walter, E.D.; Kollar, M.; Wang, Y.; Szanyi, J.; Peden, C.H.F. Understanding ammonia selective catalytic reduction kinetics over Cu/SSZ-13 from motion of the $\mathrm{Cu}$ ions. J. Catal. 2014, 319, 1-14. [CrossRef]

36. Gao, F.; Mei, D.; Wang, Y.; Szanyi, J.; Peden, C.H.F. Selective Catalytic Reduction over Cu/SSZ-13: Linking Homo- and Heterogeneous Catalysis. J. Am. Chem. Soc. 2017, 139, 4935-4942. [CrossRef] [PubMed]

37. Janssens, T.V.W.; Falsig, H.; Lundegaard, L.F.; Vennestrøm, P.N.R.; Rasmussen, S.B.; Moses, P.G.; Giordanino, F.; Borfecchia, E.; Lomachenko, K.A.; Lamberti, C.; et al. A Consistent Reaction Scheme for the Selective Catalytic Reduction of Nitrogen Oxides with Ammonia. ACS Catal. 2015, 5, 2832-2845. [CrossRef]

38. Bates, S.A.; Delgass, W.N.; Ribeiro, F.H.; Miller, J.T.; Gounder, R. Methods for $\mathrm{NH}_{3}$ titration of Brønsted acid sites in $\mathrm{Cu}$-zeolites that catalyze the selective catalytic reduction of $\mathrm{NO}_{x}$ with $\mathrm{NH}_{3}$. J. Catal. 2014, 312, $26-36$. [CrossRef]

39. Zhu, H.; Kwak, J.H.; Peden, C.H.F.; Szanyi, J. In situ DRIFTS-MS studies on the oxidation of adsorbed $\mathrm{NH}_{3}$ by $\mathrm{NO}_{x}$ over a Cu-SSZ-13 zeolite. Catal. Today 2013, 205, 16-23. [CrossRef]

40. Lezcano-Gonzalez, I.; Deka, U.; Arstad, B.; Van Yperen-De Deyne, A.; Hemelsoet, K.; Waroquier, M.; Van Speybroeck, V.; Weckhuysen, B.M.; Beale, A.M. Determining the storage, availability and reactivity of $\mathrm{NH}_{3}$ within $\mathrm{Cu}$-Chabazite-based Ammonia Selective Catalytic Reduction systems. Phys. Chem. Chem. Phys. 2014, 16, 1639-1650. [CrossRef] 
41. Xie, L.; Liu, F.; Shi, X.; Xiao, F.-S.; He,H. Effects of post-treatment method and Na co-cation on the hydrothermal stability of $\mathrm{Cu}-\mathrm{SSZ}-13$ catalyst for the selective catalytic reduction of $\mathrm{NO}_{\mathrm{x}}$ with $\mathrm{NH}_{3}$. Appl. Catal. B Environ. 2015, 179, 206-212. [CrossRef]

42. Gao, F.; Szanyi, J. On the hydrothermal stability of Cu/SSZ-13 SCR catalysts. Appl. Catal. A Gen. 2018, 560, 185-194. [CrossRef]

43. Wang, J.; Zhao, H.; Haller, G.; Li, Y. Recent advances in the selective catalytic reduction of $\mathrm{NO}_{x}$ with $\mathrm{NH}_{3}$ on Cu-Chabazite catalysts. Appl. Catal. B Environ. 2017, 202, 346-354. [CrossRef]

44. Paolucci, C.; Parekh, A.A.; Khurana, I.; Di Iorio, J.R.; Li, H.; Albarracin Caballero, J.D.; Shih, A.J.; Anggara, T.; Delgass, W.N.; Miller, J.T.; et al. Catalysis in a Cage: Condition-Dependent Speciation and Dynamics of Exchanged Cu Cations in SSZ-13 Zeolites. J. Am. Chem. Soc. 2016, 138, 6028-6048. [CrossRef]

45. Kwak, J.H.; Tran, D.; Burton, S.D.; Szanyi, J.; Lee, J.H.; Peden, C.H.F. Effects of hydrothermal aging on $\mathrm{NH}_{3}$-SCR reaction over Cu/zeolites. J. Catal. 2012, 287, 203-209. [CrossRef]

46. Paolucci, C.; Verma, A.A.; Bates, S.A.; Kispersky, V.F.; Miller, J.T.; Gounder, R.; Delgass, W.N.; Ribeiro, F.H.; Schneider, W.F. Isolation of the Copper Redox Steps in the Standard Selective Catalytic Reduction on Cu-SSZ-13. Angew. Chem. Int. Ed. 2014, 53, 11828-11833. [CrossRef]

47. Gao, F.; Kwak, J.H.; Szanyi, J.; Peden, C.H.F. Current Understanding of Cu-Exchanged Chabazite Molecular Sieves for Use as Commercial Diesel Engine DeNO ${ }_{x}$ Catalysts. Top. Catal. 2013, 56, 1441-1459. [CrossRef]

48. Gao, F.; Wang, Y.; Kollár, M.; Washton, N.M.; Szanyi, J.; Peden, C.H.F. A comparative kinetics study between $\mathrm{Cu} / \mathrm{SSZ}-13$ and Fe/SSZ-13 SCR catalysts. Catal. Today 2015, 258, 347-358. [CrossRef]

49. Verma, A.A.; Bates, S.A.; Anggara, T.; Paolucci, C.; Parekh, A.A.; Kamasamudram, K.; Yezerets, A.; Miller, J.T.; Delgass, W.N.; Schneider, W.F.; et al. NO oxidation: A probe reaction on Cu-SSZ-13. J. Catal. 2014, 312, 179-190. [CrossRef]

50. Borfecchia, E.; Lomachenko, K.A.; Giordanino, F.; Falsig, H.; Beato, P.; Soldatov, A.V.; Bordiga, S.; Lamberti, C. Revisiting the nature of $\mathrm{Cu}$ sites in the activated Cu-SSZ-13 catalyst for SCR reaction. Chem. Sci. 2015, 6, 548-563. [CrossRef]

51. Ma, L.; Cheng, Y.; Cavataio, G.; McCabe, R.W.; Fu, L.; Li, J. In situ DRIFTS and temperature-programmed technology study on $\mathrm{NH}_{3}$-SCR of $\mathrm{NO}_{x}$ over Cu-SSZ-13 and Cu-SAPO-34 catalysts. Appl. Catal. B Environ. 2014, 156-157, 428-437. [CrossRef]

52. Luo, J.; Gao, F.; Kamasamudram, K.; Currier, N.; Peden, C.H.F.; Yezerets, A. New insights into Cu/SSZ-13 SCR catalyst acidity. Part I: Nature of acidic sites probed by $\mathrm{NH}_{3}$ titration. J. Catal. 2017, 348, 291-299. [CrossRef]

53. Kovarik, L.; Washton, N.M.; Kukkadapu, R.; Devaraj, A.; Wang, A.; Wang, Y.; Szanyi, J.; Peden, C.H.F.; Gao, F. Transformation of Active Sites in Fe/SSZ-13 SCR Catalysts during Hydrothermal Aging: A Spectroscopic, Microscopic, and Kinetics Study. ACS Catal. 2017, 7, 2458-2470. [CrossRef]

54. Han, L.; Zhao, X.; Yu, H.; Hu, Y.; Li, D.; Sun, D.; Liu, M.; Chang, L.; Bao, W.; Wang, J. Preparation of SSZ-13 zeolites and their $\mathrm{NH}_{3}$-selective catalytic reduction activity. Microporous Mesoporous Mater. 2018, 261, 126-136. [CrossRef]

55. Fan, C.; Chen, Z.; Pang, L.; Ming, S.; Zhang, X.; Albert, K.B.; Liu, P.; Chen, H.; Li, T. The influence of Si/Al ratio on the catalytic property and hydrothermal stability of Cu-SSZ-13 catalysts for $\mathrm{NH}_{3}-\mathrm{SCR}$. Appl. Catal. A Gen. 2018, 550, 256-265. [CrossRef]

56. Gao, F.; Washton, N.M.; Wang, Y.; Kollár, M.; Szanyi, J.; Peden, C.H.F. Effects of Si/Al ratio on Cu/SSZ-13 $\mathrm{NH}_{3}$-SCR catalysts: Implications for the active $\mathrm{Cu}$ species and the roles of Brønsted acidity. J. Catal. 2015, 331, 25-38. [CrossRef]

57. Leistner, K.; Kumar, A.; Kamasamudram, K.; Olsson, L. Mechanistic study of hydrothermally aged Cu/SSZ-13 catalysts for ammonia-SCR. Catal. Today 2018, 307, 55-64. [CrossRef]

58. Prodinger, S.; Derewinski, M.A.; Wang, Y.; Washton, N.M.; Walter, E.D.; Szanyi, J.; Gao, F.; Wang, Y.; Peden, C.H.F. Sub-micron Cu/SSZ-13: Synthesis and application as selective catalytic reduction (SCR) catalysts. Appl. Catal. B Environ. 2017, 201, 461-469. [CrossRef]

(C) 2019 by the authors. Licensee MDPI, Basel, Switzerland. This article is an open access article distributed under the terms and conditions of the Creative Commons Attribution (CC BY) license (http://creativecommons.org/licenses/by/4.0/). 